\title{
ОСОБЛИВОСТІ ПРОТІКАННЯ СТРУМУ В ГЕТЕРОСТРУКТУРАХ ОКСИД ТИТАНУ-КРЕМНІЙ
}

\author{
Ю.С. МІЛОВАНОВ ${ }^{1}$ І.В. ГАВРИЛЬЧЕНКО ${ }^{1}$ В.Я. ГАЙВОРОНСЬКИЙ, ${ }^{2}$ \\ Г.В. КУЗНЕЦОВ, ${ }^{1}$ В.А. СКРИШЕВСЬКИЙ ${ }^{1}$ \\ ${ }^{1}$ Київський національний університет ім. Тараса Шевченка, \\ Інститут високих технологій \\ (Вул. Володимирсъка, 64, Kü̈в 01601; e-mail: juri_milovanov@ yahoo. com) \\ ${ }^{2}$ Інститут фізики НАН Украӥни \\ (Просп. Науки, 46, Київ 03028)
}

\begin{abstract}
Досліджено інжекційні механізми перенос носіїв заряду в гетероструктурах $\mathrm{Ti}-\mathrm{TiO}_{2}-(n, p) \mathrm{Si}$. Розглянуто вплив структури пористого шару $\mathrm{TiO}_{2}$ і типу кремнієвої підкладки на електричні характеристики структур. Перенос носіїв заряду відбувається за умов існування компенсуючого поляризаційного заряду на поверхні $\mathrm{TiO}_{2}$ наночастинок. Встановлено кореляції між типом адсорбованих молекул і умовами проходження струму. У структурах $\mathrm{Ti}-\mathrm{TiO}_{2}-p \mathrm{Si}$ зміна співвідношення інжектованих електронів та дірок може приводити до ефекту негативної провідності.
\end{abstract}

\section{1. Вступ}

Останнім часом значну увагу приділяють дослідженню нанокристалічних оксидних матеріалів, які характеризуються унікальними властивостями та широкими можливостями застосування. До таких сполук відноситься і оксид титану $\mathrm{TiO}_{2}$ - хімічно стабільний та недорогий матеріал, що широко застосовується для створення газових сенсорів [1-3], плівкових покриттів [4], інжекційних сонячних елементів [5-6]. Діоксид титану має унікальні фотокаталітичні властивості [7-8], є перспективним матеріалом для фотонних кристалів [9].

Сучасні розчинні технології виготовлення нанокристалічного оксиду титану забезпечують стабільність хімічного складу, відтворюваність і контрольованість мікроструктури (розмір кристалітів, величину і об'єм пор, площу питомої поверхні). Широко застосовуються методи золь-гель технології, які дозволяють синтезувати тонкодисперсні оксидні плівки з широким розподілом нанокристалітів за розмірами [10-11].

Зменшення розмірів кристалітів до порогового значення $(d<10$ нм $)$ супроводжується різким зростанням ролі поверхневої енергії і відповідною модифікацією фізико-хімічних властивостей. Для пористого оксиду титану було проведено дослідження процесів проходження носіїв заряду, визначено дрейфову рухливість та час життя електронів і дірок [12-14]. На електронний транспорт у широкозонному оксидному матеріалі значно впливають процеси інжекції та захоплення носіїв заряду при тунелюванні енергетичними рівнями в забороненій зоні $[6,15]$. У наноструктурованих матеріалах ситуація ускладнюється за наявності значної кількості електронних центрів захоплення на розвинутій внутрішній поверхні, концентрація яких досягає $10^{18} \mathrm{~cm}^{-3}$ [16]. Якщо в масивних кристалах $\mathrm{TiO}_{2}$ більша частина інжектованих носіїв зникає у процесі об'ємної рекомбінаціі, то у нанорозмірних кристалітах носії заряду встигають досягти міжкристалітних границь і їх захоплюють поверхневі пастки. Електронний транспорт у поруватих оксидних напівпровідниках дуже чутливий до адсорбованих молекул, які суттєво змінюють зарядовий стан внутрішньої поверхні. Зокрема, адсорбція полярних молекул (води, етилового спирту) дає можливість керованого формування поверхневих центрів захоплення носіїв заряду [1], що визначають інжекційні особливості наноструктурованого матеріалу.

Практично не досліджено особливості інжекційних механізмів переносу носіїв у контактах нанострукту- 
рованого $\mathrm{TiO}_{2}$ з іншими напівпровідниками, зокрема кремнієм $[1,6]$. У таких гетероструктурах з'являються додаткові можливості керування інжекційними потоками носіїв заряду та їх захоплення енергетичними пастками. У даній роботі досліджено механізми переносу носіїв заряду у структурах зі сформованими методами золь-гель технології нанокристалічними плівками $\mathrm{TiO}_{2}$ на монокристалічних кремнієвих підкладках різного типу провідності: метал- $\mathrm{TiO}_{2}-n \mathrm{Si}$; метал- $\mathrm{TiO}_{2}-p \mathrm{Si}$. Електричні властивості гетероструктур досліджено у різних газових середовищах (повітря, пари води, пари етилового спирту).

\section{2. Методика експерименту}

Плівки діоксиду титану виготовляли методом зольгель синтезу. До ізопропанолу, який використовували як розчинник, додавали тетраізопрооксид титану та $\alpha$-терпінеол, який надавав додаткової в'язкості розчину. Для утворення поруватих плівок у ролі комплексоутворюючих реагентів застосовували поліетиленгліколі з молекулярною масою $M=300$ г/моль (зразки $\left.\mathrm{TiO}_{2}-300\right)$ і $M=1000$ г/моль (зразки $\mathrm{TiO}_{2}-1000$ ). Концентрація $\mathrm{TiO}_{2}$ у прекурсорі становила $\sim 4 \%$ (за масою).

Оксидні плівки наносили на поверхню кремнієвої пластини методом витягування 3 прекурсору 3 подальшим відпалом при температурі $450{ }^{\circ} \mathrm{C}$. Така обробка забезпечувала повне видалення органічних сполук і формування нанокристалічної анатазної фази $\mathrm{TiO}_{2}$ [8]. Згідно з даними просвічуючої електронної мікроскопії у зразках $\mathrm{TiO}_{2}-1000$ середній діаметр нанокристалітів становив 15 нм (площа поверхні $~ 70$ $\mathrm{m}^{2} /$ г), а зразки $\mathrm{TiO}_{2}-300$ відрізняються присутністю двох груп нанокристалітів з середнім діаметром 3 нм і 20 нм (площа поверхні $\sim 100 \mathrm{~m}^{2} /$ г). Пористість оксидного шару розраховували з урахуванням нерегулярності форми частинок згідно з [17]:

$P \frac{1-\varepsilon_{\mathrm{eff}}}{1+2 \varepsilon_{\mathrm{eff}}}+(1-P) \frac{\varepsilon_{\mathrm{TiO}_{2}}-\varepsilon_{\mathrm{eff}}}{\varepsilon_{\mathrm{TiO}_{2}}+2 \varepsilon_{\mathrm{eff}}}=0$,

де $P$ - пористість, $\varepsilon_{\text {eff }}, \varepsilon_{\mathrm{TiO}_{2}}-$ діелектричні проникності пористого середовища і твердотільної анатазної фази $\left(\varepsilon_{\mathrm{TiO}_{2}}=40\right)$. Пористість для зразків $\mathrm{TiO}_{2}-1000$ становила - 33-35\%, для $\mathrm{TiO}_{2}-300-38-40 \%$.

Для проведення електричних вимірювань на шар поруватого оксиду титану методом електроннопроменевого випаровування наносили контакт Ті товщиною 30 нм і діаметром 1 мм. Дифузія донорної домішки титану приводить до зменшення контактного опору і стимулює існування провідності $n$ -

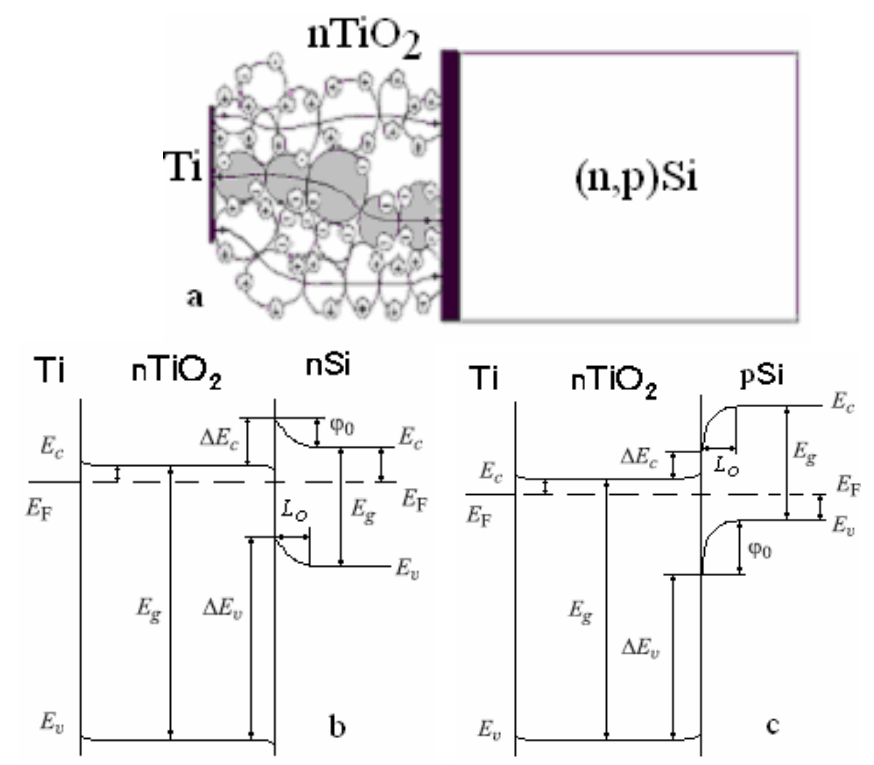

Рис. 1. Структура (a) та енергетичні діаграми гетероструктур $\mathrm{Ti}_{-} \mathrm{TiO}_{2}-n \mathrm{Si}(b)$ та $\mathrm{Ti}-\mathrm{TiO}_{2}-p \mathrm{Si}(c)$

типу в оксидній плівці $\mathrm{TiO}_{2}$. Електричні параметри виготовлених гетероструктур досліджували методами імпеданс-спектроскопії, вольт-амперних та вольтфарадних характеристик [18].

Пари води або етилового спирту вводили у камеру зі зразком через систему прокачки через воду або водний розчин спирту. У ролі носія-газу використовували пари азоту, який не впливає на електрофізичні та оптичні властивості досліджуваних структур.

\section{3. Експериментальні результати та їх обговорення}

\section{1. Вольт-амперні характеристики}

Провідність гетероструктур $\mathrm{Ti}_{-}-\mathrm{TiO}_{2}-(n, p) \mathrm{Si}$ визначається сумою провідностей проміжного наноструктурованого оксидного шару та бар'єрної області просторового заряду у напівпровіднику (рис. 1). Структури мають випростуючі вольт-амперні характеристики, причому знак випростування узгоджується 3 типом провідності кремнієвої підкладки.

На рис. 1 показано структуру та енергетичні діаграми гетероструктур $\mathrm{Ti}-\mathrm{TiO}_{2}-(n, p) \mathrm{Si}$, побудовані на основі відомих значень ширини забороненої зони $E_{g}\left(\mathrm{TiO}_{2}\right)=3,1 \mathrm{eB} ; E_{g}(\mathrm{Si})=1,1 \mathrm{eB} ;$ спорідненості до електрона $\chi\left(\mathrm{TiO}_{2}\right)=4,3 \mathrm{eB} ; \chi(\mathrm{Si})=4,0 \mathrm{eB}$ та роботи виходу $\Psi(\mathrm{Ti})=4,4$ eB $[17,19]$. Енергії рівня Фермі $E_{\mathrm{F}}$, висоти потенціального бар'єра $\varphi_{0}$, енергетичного розриву в зоні провідності $\Delta E c$ та валентній 


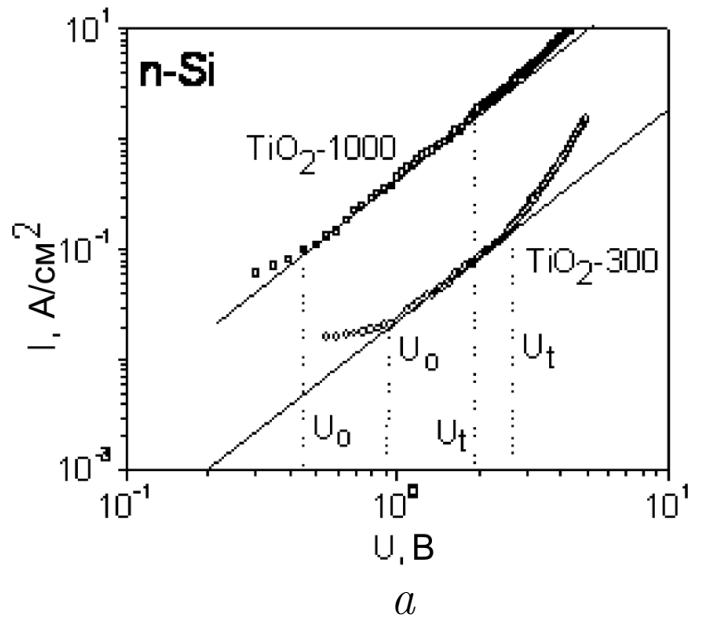

Рис. 2. Вольт-амперна характеристика структур $\mathrm{Ti}-\mathrm{TiO}_{2}-n \mathrm{Si}(a)$ та $\mathrm{Ti}_{-} \mathrm{TiO}_{2}-n \mathrm{Si}$ (б) у координатах COП3

зоні $\Delta E_{v}$ визначено з урахуванням експериментально отриманих значень концентрацій носіїв заряду в $\mathrm{TiO}_{2}$ та $\mathrm{Si}$. Для ізотипних гетероструктур $\mathrm{Ti}-\mathrm{TiO}_{2}-$ $n \mathrm{Si}$, на рис. 1, енергетичні параметри мають значення: $E_{c}-E_{\mathrm{F}}=0,1 \mathrm{eB}\left(n \mathrm{TiO}_{2}\right) ; E_{c}-E_{\mathrm{F}}=0,2 \mathrm{eB}$ $(n \mathrm{Si}) ; \varphi_{0}=0,2 \mathrm{eB} ; \Delta E_{c}=0,3 \mathrm{eB} ; \Delta E_{v}=2,3 \mathrm{eB}$ (бар'єр для струму в зоні провідності). Відповідні параметри для анізотипних гетероструктур $\mathrm{Ti}-\mathrm{TiO}_{2}-$ $p \mathrm{Si}: E_{c}-E_{\mathrm{F}}=0,1 \mathrm{eB}\left(n \mathrm{TiO}_{2}\right) ; E_{\mathrm{F}}-E_{v}=0,2 \mathrm{eB}$ $(p \mathrm{Si}) ; \varphi_{0}=0,5 \mathrm{eB} ; \Delta E_{c}=0,3 \mathrm{eB} ; \Delta E_{v}=2,3 \mathrm{eB}$ (бар'єр для струму у валентній зоні). Оцінки товщин $L_{o}$ збіднених областей в $\mathrm{TiO}_{2}$ та $\mathrm{Si}$ згідно 3 [17] дають значення $L_{o}(\mathrm{Si}) \gg L_{o}\left(\mathrm{TiO}_{2}\right)$, тобто можна вважати, що область просторового заряду досліджуваних гетероструктур повністю формується у кремнiï.

При прямому включенні опір області просторового заряду кремнію різко зменшується з ростом напруги, і внесок високоомного оксидного шару стає визначальним. На рис. 2 показано залежності струму від зовнішньої напруги при прямому включенні структур $\mathrm{Ti}-\mathrm{TiO}_{2}-n \mathrm{Si}$ (позитивний потенціал на титановому контакті) та $\mathrm{Ti}-\mathrm{TiO}_{2}-p \mathrm{Si}$ (негативний потенціал на титановому контакті). У подвійному логарифмічному масштабі $\lg I \sim \lg U$ вольт-амперна характеристика має лінійні ділянки, які відрізняються своїм нахилом: на початковому етапі виконується закон Ома, для інтервалу напруги $U \sim 1-5$ В характерною є квадратична залежність $I \sim U^{2}$, а за подальшого збільшення напруги спостерігається пришвидшене зростання струму. Характерна квадратична залежність струму від напруги в досліджуваних структуpax є типовою для струмів, обмежених просторовим зарядом (СОПЗ).

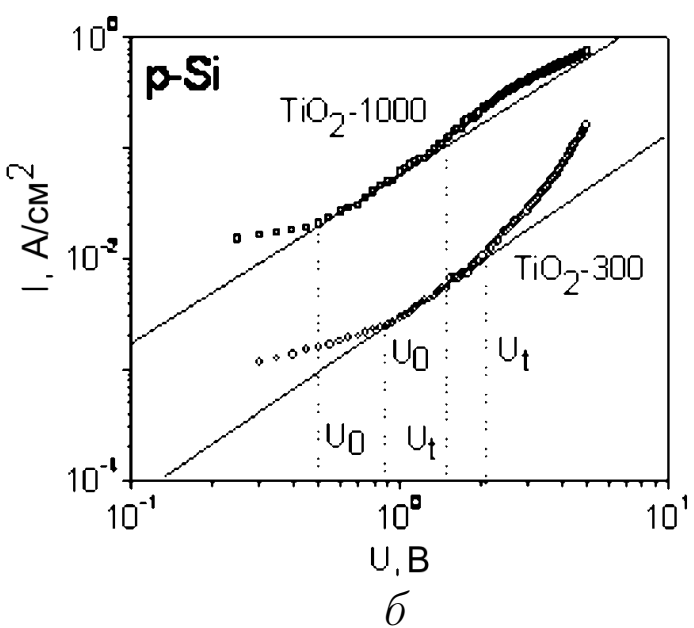

На початковій омічній області вольт-амперної характеристики концентрація носіїв заряду є близькою до рівноважної, що дозволяє визначити питомий опір оксидної плівки. Більш впорядковані і однорідні зразки $\mathrm{TiO}_{2}-1000$ мають значення питомого опору оксидного шару $\rho \approx 10^{4}-10^{5}$ Ом.см. У зразках $\mathrm{TiO}_{2}-300$ невпорядкованість структури і більша площа питомої поверхні зумовлюють підвищення концентрації поверхневих центрів захоплення, і відповідне зростання питомого опору до $\rho \approx 10^{6}$ Ом.см. Крім того, наявність у зразках $\mathrm{TiO}_{2}-300$ двох груп нанокристалітів різного розміру приводить до інтенсифікації процесів міжкристалітної дифузії носіїв заряду, які також можуть захоплюватися молекулярними пастками [8].

Концентрація рівноважних вільних носіїв заряду $n_{0}$ та їх дрейфова рухливість $\mu$ в оксидному шарі визначались на різних ділянках вольт-амперної характеристики: в омічній області згідно з [19]

$I=e n_{0} \mu \frac{U}{L}$,

в області квадратичної залежності згідно з

$I=\frac{\mu \varepsilon \varepsilon_{0} U^{2}}{L^{3}}$

та за величиною напруги $U_{0}$ переходу від лінійної до квадратичної залежності:

$U_{0}=\frac{4 e n_{0} L^{2}}{3 \varepsilon \varepsilon_{0}}$,

де $U, I$ - відповідно, напруга та густина струму у структурі, $\mu$ - рухливість, $\varepsilon, \varepsilon_{0}$ - діелектрична проникність оксидного шару та вакууму, $n_{0}$ - рівноважна концентрація, $L$ - товщина шару $\mathrm{TiO}_{2}$. Збіг значень концентрації $n_{0} \approx 1 \cdot 10^{17} \mathrm{~cm}^{-3}$ та рухливості 
$\mu \approx 10^{-3}-10^{-4}$ см $^{2} /$ В·с при визначенні різними методами підтверджує припущення про домінуючий внесок струмів, обмежених просторовим зарядом.

Температурна залежність дрейфової рухливості в області температур $T=300-400 \mathrm{~K}$ характеризується енергією активації $E_{\mu} \approx 0,13-0,15 \mathrm{eB}$. Можна припустити, що перенос носіїв заряду через шар $\mathrm{TiO}_{2}$ здійснюється за допомогою стрибків по локалізованих електронних станах. Для стрибкового механізму значення дрейфової рухливості визначається згідно з виразом:

$\mu=\frac{e \nu R^{2}}{6 k T} \exp \left(-\frac{E_{\mu}}{k T}-\frac{R}{r}\right)$,

де $\nu$ - фононна частота, $R$ - довжина стрибка, $r$ - радіус локалізації. Отримані значення рухливості $\mu \approx 10^{-3}-10^{-4} \mathrm{~cm}^{2} /$ В·с при характерних значеннях фононної частоти $\nu \approx 10^{12} \mathrm{c}^{-1}$ відповідають довжині стрибка $R<1$ нм, що співрозмірно з міжатомними відстанями у шарі $\mathrm{TiO}_{2}$.

Важливим фактором впливу на електропровідність наноструктурованого оксиду титану є наявність значної кількості центрів захоплення носіїв заряду [20]. У випадку струму, обмеженого просторовим зарядом, оцінку концентрації пасток можна здійснити за значенням порогової напруги їх заповнення $U_{t}$ (рис. 2):

$U_{t}=\frac{e N_{t} L^{2}}{2 \varepsilon \varepsilon_{0}}$,

де $U_{t}$ - напруга порогового заповнення пасток, $N_{t}$ - концентрація центрів захоплення. Для зразків типу $\mathrm{TiO}_{2}-1000$ концентрація центрів захоплення становить $N_{i} \sim 10^{16} \mathrm{~cm}^{-3}$, що в $3-5$ разів менше, ніж для $\mathrm{TiO}_{2}-300$, що узгоджується з отриманими результатами досліджень дефектних центрів у нанокристалічному анатазі методом спектроскопії електронного парамагнітного резонансу [8].

Вплив типу провідності напівпровідникової кремнієвої підкладки на процеси переносу носіїв заряду можна оцінити із наведених на рис. 3 залежностей провідності структур $\mathrm{Ti}-\mathrm{TiO}_{2}-n \mathrm{Si}$ та $\mathrm{Ti}-\mathrm{TiO}_{2}-p \mathrm{Si}$ від зовнішньої напруги. Спостерігається асиметрична залежність G-V від полярності напруги, яка визначається випростуючим потенціальним бар'єром на межі поділу між оксидним шаром $\mathrm{TiO}_{2}$ і кремнієвою підкладкою.

Для структур $\mathrm{Ti}-\mathrm{TiO}_{2}-n \mathrm{Si}$ реалізується режим монополярної інжекції електронів в оксидний шар. Залежно від полярності прикладеної напруги роль інжектуючого катода виконують Ті або $n$-Si електроди. Порушення електронейтральності об'єму зразка приводить до обмеження струму виникаючим просторовим зарядом. Всі інжектовані електрони залишаються у зоні провідності і беруть участь як в утворенні об'ємного просторового заряду, так і в перенесенні струму. У пропускному напрямку при напрузі $U>3-4$ В спостерігається вихід у режим насичення, що зумовлено незначними змінами концентрації інжектованих носіїв заряду у шарі $\mathrm{TiO}_{2}$. В цьому випадку характерна для СОПЗ квадратична залежність струму може змінюватися режимом малого сигналу (рис. 2,a).

$\mathrm{Y}$ структурах $\mathrm{TiO}_{2}-p \mathrm{Si}$ у пропускному напрямку реалізується режим подвійної інжекції носіїв заряду в оксидний шар $\mathrm{TiO}_{2}$ : електронів з титанового електрода і дірок з прямо зміщеного гетеропереходу $\mathrm{TiO}_{2}-$ $p \mathrm{Si}$. На початковому етапі $(U<0)$ рекомбінація інжектованих неосновних носіїв зумовлює зменшення концентрації електронів, що приводить до появи області негативної провідності (рис. 3,6, криві 1, 2). Ефект негативної диференціальної провідності, зумовлений наявністю глибоких пасток у $\mathrm{TiO}_{2}$ з енергією активації 175-375 меВ, вже спостерігався нами в гетероструктурах на основі $\mathrm{TiO}_{2}[20]$.

Під час подальшого зростання прикладеної напруги $(U>5 \mathrm{~B})$ основною компонентою струму в області високої інжекції стає нейтралізуючий потік інжектованих електронів, що зумовлює процес зростання провідності. При значному рівні біполярної інжекції електрична нейтральність встановлюється за час прольоту, і струм обмежується не лише рекомбінацією, але і виникаючим просторовим зарядом захоплених та вільних носіїв. Підвищення концентрації електронно-діркових пар і відповідне зростання провідності оксидного шару більше проявляються для однорідних зразків типу $\mathrm{TiO}_{2}-1000$ (рис. $1, б$ ).

При зворотній полярності (позитивний потенціал на $\mathrm{Ti}$ контакті) в структурах $\mathrm{Ti}-\mathrm{TiO}_{2}-p$-Si роль електронної та діркової складових інжекційного струму стає несуттєвою. Відхилення від характерного для СОПЗ вигляду може визначатися впливом зворотно включеного потенціального бар'єра на межі поділу оксидного шару і $p \mathrm{Si}$-підкладки.

На величину ефекту негативної провідності істотно впливають параметри структури та умови вимірів (частота, температура, склад газового середовища). У зразках $\mathrm{TiO}_{2}-1000$ значення диференціальної провідності на частоті $f=10^{6}$ Гц у 2-3 рази перевищує провідність зразків ТіО-300 з такою ж товщиною оксидного шару, що узгоджується з вимірами провідності на постійному струмі. При підвищенні температури ємність і провідність гетеростру- 

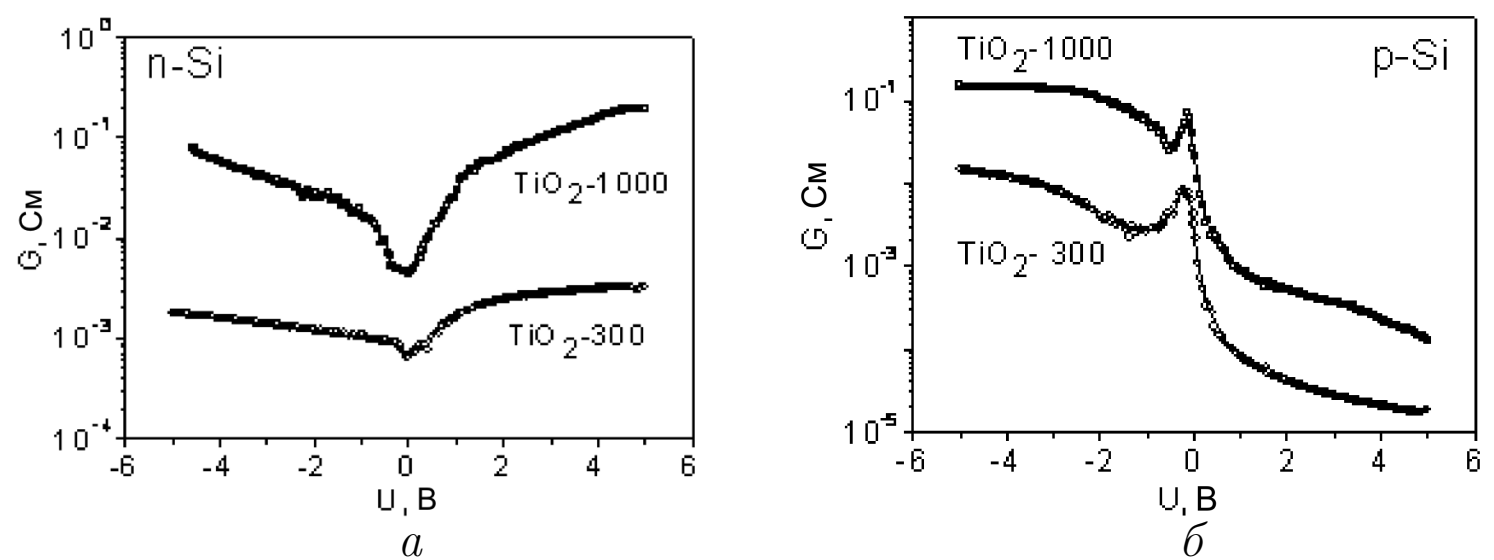

Рис. 3. Залежність провідності від прикладеної напруги для структур $\mathrm{Ti}_{-} \mathrm{TiO}_{2}-n \mathrm{Si}(a)$ та $\mathrm{Ti}_{-} \mathrm{TiO}-p \mathrm{Si}($ б)

ктур зростає в усьому діапазоні частот, що зумовлено збільшенням концентрації термічно рівноважних пар електрон-дірка і зміною їх зарядових співвідношень.

\section{2. Формування провідних каналів}

Процеси електронного транспорту у пористому шаpi $\mathrm{TiO}_{2}$ можна інтерпретувати у межах механізму переносу носіїв заряду у дисперсній системі з'єднаних нанокристалітів $\mathrm{TiO}_{2}$ (рис. 1,a). Деякі автори трактують провідність шару пористого оксиду з точки зору часу прольоту носіїв заряду [21]. У роботі [22] запропоновано схему формування провідних каналів для інжектованих носіїв, яка враховує роль зарядового стану внутрішньої поверхні оксидного шару. Формування шляхів і часу проходження носіїв заряду залежить від умов інжекції, природи та заповнення поверхневих та об'ємних пасток, локального поляризаційного заряду нанокристаліта. Знак зарядженості визначається типом біографічних та адсорбованих поверхневих центрів (позитивний для донорів або негативний для акцепторів). Значення поверхневого заряду залежить не лише від концентрації і заповнення поверхневих пасток, але і від поляризації присутніх дипольних молекул.

$\mathrm{У}$ досліджуваних структурах розміри наночастинок $\mathrm{TiO}_{2}$ співрозмірні з довжиною екранування, що приводить до практично повного спрямлення енергетичних зон і рівномірної зарядженості об'єму кристаліта. Наявність позитивного поверхневого заряду зумовлює підвищення положення рівня Фермі і акумуляцію інжектованих електронів в об'ємі кристаліта. Утворення провідних шляхів здійснюється в умовах неоднорідності загального електричного поля в оксидному шарі і вимагає часу для насичення пасток та поляризації $\mathrm{TiO}_{2}$ наночастинок. У випадку електрон- ної інжекції електрони спочатку захоплюються пастками ближніх до титанового катода наночастинок $\mathrm{TiO}_{2}$, формуючи екрануючий поляризаційний позитивний заряд на їх поверхні. Поступово електрони проникають далі в об'єм оксидного шару, утворюючи провідні канали з позитивно зарядженою поверхнею наночастинок (рис. 1, незаштрихований канал). Інжекція дірок у такому каналі блокується електричним полем, що виникає при поляризації. За негативного поверхневого заряду в системі нанокристалітів формуються канали, які є провідними для дірок і одночасно заблокованими для електронів (рис. 1, заштрихований канал).

\section{3. Вплив адсорбцї}

Адсорбція - один із ефективних методів зміни концентрації і зарядового стану поверхневих пасток. Значення сформованого поверхневого заряду залежить від можливостей атомів адсорбата захопити або віддати електрон. Відомо, що в атмосфері на внутрішній поверхні нанокристалічного $\mathrm{TiO}_{2}$ інтенсивно формуються кисневовміщуючі радикальні групи, які переважно визначають процеси акцепторно-донорної взаємодії з інжектованими носіями заряду [8].

Атоми адсорбату, потрапляючи на поверхню напівпровідника, залежно від своїх фізико-хімічних властивостей, прагнуть захопити або віддати електрон. У повітряному середовищі на поверхні нанокристалітів інтенсивно адсорбується кисень. Атоми кисню з високою електронегативністю локалізують біля себе електрон напівпровідника, утворюючи акцепторні аніон-радикали $\mathrm{O}^{-2}, \mathrm{O}^{-3}$. Іншим важливим газовим компонентом атмосфери є пари води, молекули якої характеризуються значним дипольним моментом. Молекули $\mathrm{H}_{2} \mathrm{O}$ дисоціюють на поверхні пор i 


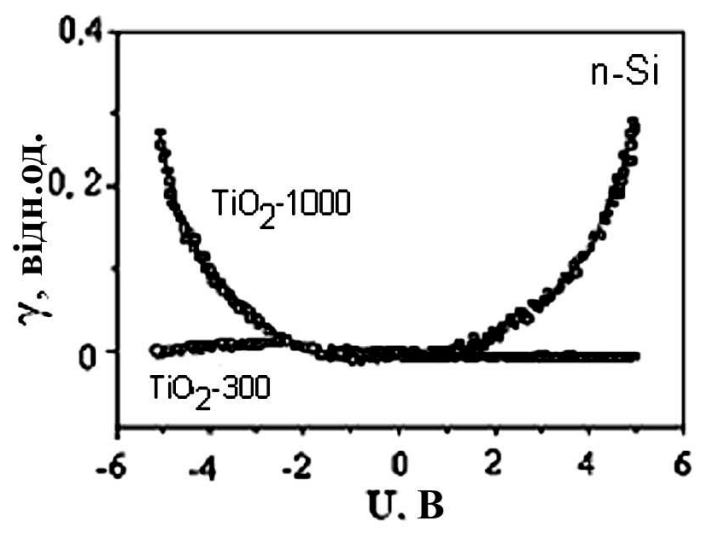

$a$

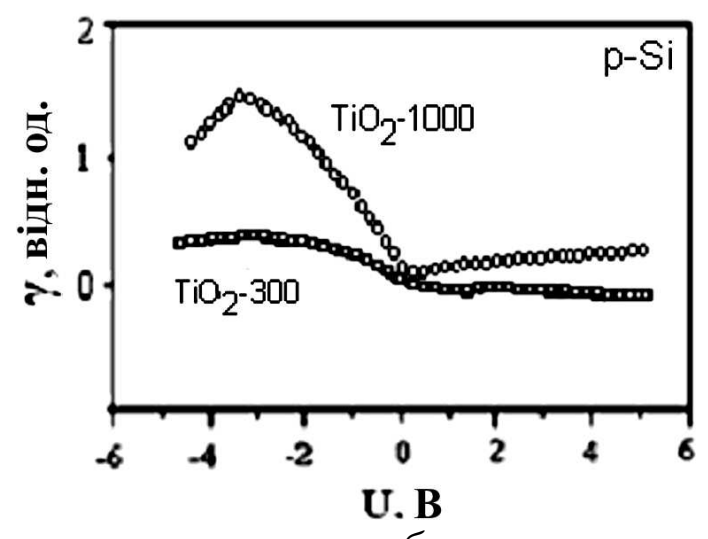

б

Рис. 4. Залежність адсорбційної чутливості від напруги для структур $\mathrm{Ti}-\mathrm{TiO}_{2}-n \mathrm{Si}(a)$ та $\mathrm{Ti}_{-} \mathrm{TiO}-p \mathrm{Si}($ б) під час продування у парах $\mathrm{H}_{2} \mathrm{O}$

різнойменні заряди розділяються внаслідок різниці ïx коефіцієнтів дифузії в оксидній плівці (іони $\mathrm{H}^{+}$ - рухливі, $\mathrm{OH}^{-}$- локалізовані в гідроксильних групах). Дисоціації води сприяе і наявність на поверхні оксиду хемосорбованого кисню, що згідно з реакцією: $\mathrm{H}_{2} \mathrm{O}+\mathrm{O}^{-}+e^{-} \rightarrow 2 \mathrm{OH}^{-}$також може бути причиною збільшення провідності оксидного шару. Пористий оксид титану є гідрофільним матеріалом і містить певну кількість адсорбованої води навіть у сухій атмосфері. Адсорбовані донорні молекули води віддають свій електрон у зону провідності або центру на поверхні напівпровідника, утворюючи поверхневі молекулярні групи $\left(\mathrm{HO}_{2}\right)^{+},(\mathrm{OH})^{-}$з позитивним зарядом.

Адсорбційну чутливість оцінювали по значенню відносної зміни провідності $\gamma=\frac{G_{A}-G_{0}}{G_{0}}$, де $G_{0}, G_{A}$ - відповідно, значення електропровідності у повітрі і під час продування у насичених парах води (рис. 4).

Позитивна зарядженість внутрішньої поверхні пористого $\mathrm{TiO}_{2}$ забезпечувалася адсорбцією донорних молекул у газовому середовищі парів води та етанолу, що характеризуються наявністю значного дипольного моменту. Продування зі сталим градієнтом парціального тиску парів води або спирту активізує донорно-акцепторні процеси переносу і приводить до підвищення адсорбційної здатності поверхні $\mathrm{TiO}_{2}$. Зростання провідності структур корелюе зі значеннями дипольного моменту адсорбованих полярних молекул.

Для структур $\mathrm{Ti}_{-}-\mathrm{TiO}_{2}-n \mathrm{Si}$ спостерігається практично симетричне зростання адсорбційної чутливості від прикладеної напруги, зумовлене збільшенням кількості провідних каналів (рис. 4,a). Зростанню провідності сприяе збільшення дифузійної довжи- ни та зменшення темпу рекомбінації інжектованих електронів за рахунок захоплення носіїв заряду на пастки. Після заповнення пасток транспорт електронів в оксидному шарі стає майже недисперсійним. $\mathrm{У}$ розупорядкованих зразках $\left(\mathrm{TiO}_{2}-300\right)$ спостерігається зниження адсорбційної чутливості, пов'язане 3 ускладненням перколяційного проходження і обмеженнями переносу носіїв заряду в наночастинках 3 малими розмірами [4].

Для структур $\mathrm{Ti}-\mathrm{TiO}_{2}-p \mathrm{Si}$ адсорбція полярних молекул змінюе не тільки значення струму, але й характер залежності струму від прикладеної напруги. В умовах мінімізації інжекційних струмів (+ на $\mathrm{Ti}$ електроді) адсорбційна чутливість наближається до нульової, що дає змогу керувати параметрами чутливості за рахунок зміни полярності напруги (рис. 4,b).

\section{4. Висновки}

Процеси інжекції носіїв заряду в нанокристалічному шарі $\mathrm{TiO}_{2}$ здійснюються через систему провідних каналів в умовах суттєвого впливу зарядового стану внутрішньої поверхні. Формування шляхів і часу проходження носіїв заряду залежить від властивостей інжектуючого контакту, природи і заповнення поверхневих та об'ємних пасток, локальної поляризації нанокристаліта. Значення поверхневого компенсуючого заряду визначається типом та концентрацією біографічних й адсорбованих поверхневих центрів. У структурах $\mathrm{Ti}-\mathrm{TiO}_{2}-p \mathrm{Si}$ зміна співвідношення інжектованих електронів і дірок може приводити до ефекту негативної провідності. 
Роботу виконано за фінансової підтримки Державного агентства з питань науки, інновацій та інформатизації України (проекти Ф40.7/15 та М/90-2010).

1. V.A. Skryshevsky, V.A. Vikulov, O.V. Tretyak, V.M. Zinchuk, F. Koch, and Th. Dittrich, Phys. Status Solidi A 197, 534 (2003).

2. S.K. Hazra, S. Roy, and S. Basu, Mater. Sci. Eng. B 110, 195 (2004).

3. G. Korotcenkov and B.K. Cho, Crit. Rev. Solid State Mater. Sci. 35, 1 (2010).

4. S. Ben Amor, L. Guedri, G. Baud, M. Jacquet, and M. Ghedira, Mater. Chem. Phys. 77, 903 (2002).

5. R. Komiya, J. Photochem. Photobio A 164, 123 (2004).

6. Th. Dittrich, V. Zinchuk, V. Skryshevskyy, I. Urban, and O. Hilt, J. Appl. Phys. 98, 104501 (2005).

7. A. Ennaoui, B.R. Sankapal, V. Skryshevsky, and M.Ch. Lux-Steiner. Sol. Energy Mater. Sol. Cells 90, 1533 (2006).

8. E.A. Konstantinova, V.Ya. Gayvoronskiy, V.Yu. Timoshenko, and P.K. Kashkarov, Semiconductors 44, 1093 (2010).

9. P. Viswanathamurthi, N. Bhattarai, C.K. Kim, H.Y. Kim, and D.R. Lee, Inorg. Chem. Commun. 7, 679 (2004).

10. O. Harizanov and A. Harizanova, Sol. Energy Mater. Sol. Cells 63, 185 (2002).

11. Yingchun Zhu and Chuanxian Ding, J. Europ. Ceram. Soc. 20, 127 (2000).

12. G. Kron, T. Egerter, J.H. Werner, and U. Rau, J. Phys. Chem. B 107, 3556 (2003).

13. P.M. Kumar, S. Badrinarayanan, and M. Sastry, Thin Solid Films 358, 122 (2000).

14. A. Zaban, A. Meier, and B.A. Gregg, J. Phys. Chem. B 101, 7985 (1997).

15. V.A. Skryshevskyy, Th. Dittrich, and J. Rappich, Phys. Status Solidi A 201, 157 (2004).

16. E.A. Lebedev and Th. Dittrich, Semiconductors 36, 1268 (2002).

17. A.L. Fahrenbruch and R.H. Bube, Fundamentals of Solar Cells: Photovoltaic Solar Energy Conversion (Academic Press, New York, 1983).

18. A.Yu. Karlach, G.V. Kuznetsov, S.V. Litvinenko, Yu.S. Milovanov, and V.A. Skryshevsky, Semiconductors 44, 1342 (2010).

19. В.Б. Лазарев, В.Б. Лазарев, В.Г.Красов, И.С. Шаплыгин, Электропроводность окисных систем и пленочных структур (Наука, Г., 1979).
20. A.I. Manilov, A.M. Veremenko, I.I. Ivanov, and V.A. Skryshevsky, Physica E 41, 36 (2008).

21. H. Wittmer, S. Holten, H. Kliem, and H. Breuer, Phys. Status Solidi A 181, 461 (2000).

22. V. Kytin and Th. Dittrich, Phys. Status Solidi A 185, $461(2001)$.

Одержано 20.09.11

\section{ОСОБЕННОСТИ ТОКОПРОХОЖДЕНИЯ \\ В ГЕТЕРОСТРУКТУРАХ ОКСИД ТИТАНА-КРЕМНИЙ}

Ю.С. Милованов, И.В. Гаврилъченко,

В.Я. Гайворонский, Г.В. Кузнецов, В.А. Скришевский

$\mathrm{P}$ е $з$ ю м е

Исследованы инжекционные механизмы переноса носителей заряда в гетероструктурах $\mathrm{Ti}-\mathrm{TiO}_{2}-(n, p) \mathrm{Si}$. Рассмотрено влияние структуры пористого слоя $\mathrm{TiO}_{2}$ и типа кремниевой подложки на электрические характеристики структур. Прохождение носителей заряда происходит в условиях существования компенсирующего поляризационного заряда на поверхности $\mathrm{TiO}_{2}$ наночастиц. Установлены корреляции между типом адсорбированных молекул и условиями прохождения тока. В структурах $\mathrm{Ti}-\mathrm{TiO}_{2}-p \mathrm{Si}$ изменение соотношения инжектированных электронов и дырок может приводить к эффекту отрицательной проводимости.

\section{PECULIARITIES OF CURRENT TRANSPORT} IN TITANIUM OXIDE-SILICON HETEROSTRUCTURES

Yu.S. Milovanov ${ }^{1}$, I.V. Gavrilchenko ${ }^{1}$, V.Ya. Gayvoronsky ${ }^{2}$, G.V. Kuznetsov ${ }^{1}$, V.A. Skryshevsky ${ }^{1}$

\section{${ }^{1}$ Institute of High Technologies,}

Taras Shevchenko National University of Kyiv

(64, Volodymyrska Str., Kyiv 01601, Ukraine;

e-mail: juri_milovanov@yahoo.com),

${ }^{2}$ Institute of Physics, Nat. Acad. of Sci. of Ukraine

(46, Nauka Ave., Kyiv 03680, Ukraine)

$\mathrm{S} u \mathrm{~mm}$ a r y

The mechanisms of charge carrier injection into $\mathrm{Ti}-\mathrm{TiO}_{2}-(n, p)-\mathrm{Si}$ heterostructures have been studied. The influence of the porous $\mathrm{TiO}_{2}$ structure and the silicon substrate type on the electrical characteristics of heterostructures is analyzed. The charge transfer is shown to be accompanied by the appearance of a compensating polarization charge on the surface of $\mathrm{TiO}_{2}$ nanoparticles. Correlations between the type of adsorbed molecules and the conditions of the current flow have been determined. In $\mathrm{Ti}-\mathrm{TiO}_{2}-p-\mathrm{Si}$ heterostructures, a change of the ratio between the numbers of injected electrons and holes can lead to the negative-conductivity effect. 